\title{
Seasonal changes in hemocytes and serum defense factors in the blue mussel Mytilus galloprovincialis
}

\author{
M. M. Santarém, J. A. F. Robledo, A. Figueras* \\ Departamento de Biología y Patología de Organismos Marinos, Instituto de Investigaciones Marinas-CSIC, E-36208 Vigo, Spain
}

\begin{abstract}
Hemolymph characteristics were examined in experimentally cultured blue mussels Mytilus galloprovincialis Lmk. from 2 locations in the Ría de Vigo (NW Spain). The highest protein, lysozyme and agglutinin values were found in July. The increase of agranular hemocytes and the decrease of granular blood cells in April was associated with parasitism by Mytilicola intestinalis. No linkage was found between the number of circulating hemocytes and hemolymph component (lysozyme, agglutinins and proteins) concentrations with parasitism. It is suggested that the number of circulating hemocytes, lysozyme and proteins levels and agglutination titer were related to the reproductive cycle and varied according to the location of mussels.
\end{abstract}

KEY WORDS: Hemolymph - Lysozyme Proteins - Agglutination titers Hemocytes - Mussels

\section{INTRODUCTION}

Hemocytes represent the most important internal immune defense system against foreign material in marine bivalve molluscs (Cheng 1981, Bayne 1983, Rasmussen et al. 1985). The exact function of bivalve humoral factors in internal defense is not clear (Chu 1988). Variations in the number and type of hemocytes in bivalve molluscs experimentally challenged with foreign material have been described (Farley 1968, Moore \& Lowe 1977, Suresh \& Mohandas 1990). Seasonal changes in the environmental factors affect number, type and defensive capacity of hemocytes (Feng 1965, Thompson et al. 1978, Fisher et al. 1989). However, it is believed that changes in lysozyme, agglutinin and proteins reflect internal defense mechanisms (Tripp 1966, McDade \& Tripp 1967, Feng \& Canzonier 1970. Hardy et al. 1976). Alterations in the components of the hemolymph associated with parasites have been attributed to the release of materials from damaged tissue (Feng \& Canzonier 1970, Ford et

- Addressee for correspondence al. 1993), rapid utilisation of host nutrients by the parasite, decrease of the host's feeding rate (Bayne et al. 1979 ) and decrease of reproductive activity (Mulvey \& Feng 1981). Numerous investigations (Mulvey \& Feng 1981, Fisher \& Newell 1986, Chu \& La Peyre 1989, Ford et al. 1993) have documented seasonal and environmental variations in hemolymph constituents which may be linked to the reproductive cycle.

The parasites and pathological conditions observed in cultured blue mussels Mytilus galloprovincialis Lmk. from Galicia (NW Spain) have been described by Fernández et al. (1990), Figueras et al. (1991) and Gómez Mourelle (1993). Mytilicola intestinalis is the parasite that reaches the highest prevalence in mussels from this area. The same authors reported that this copepod causes hemocytic infiltration and damage in the tissues. However, to our knowledge, nothing has been reported about the possible effects of such parasites on the hemolymph components of $M$. galloprovincialis.

In this study, we analyse the influence of exogenous (temperature and food availability) and endogenous (reproductive cycle) factors on the variations in hemolymph. The relationship of hemolymph constituents 
with Mytilicola intestinalis parasitizing mussels was also investigated, comparing the hemolymph of parasitized and non-parasitized mussels.

\section{MATERIALS AND METHODS}

Animals. Blue mussels Mytilus galloprovincialis, $47.3 \mathrm{~mm}$ in mean length $(\mathrm{SD}=4.14)$ and $12.3 \mathrm{~g}$ in mean weight ( $\mathrm{SD}=3.63$ ), were taken from collectors in Meira in the Ría de Vigo (middle area, water temperature ranging between 12.3 and $20.3^{\circ} \mathrm{C}$ and salinity between 29 and 35 ppt; Prego \& Fraga 1992) in February 1990. The mussels were placed in baskets submerged to $5 \mathrm{~m}$ from the rafts in Liméns (outer area of Ría de Vigo, salinity between 32 and 35 ppt) and Domayo (inner area, salinity between 26 and 35 ppt) (Prego \& Fraga 1992) (Fig. 1). These localities represent 2 areas where mussels are cultured, the parasite load being higher in mussels cultured in the inner area than in the outer area of the Ría de Vigo (Figueras et al. 1991, Robledo unpubl.). Between April 1990 and January 1991, 20 mussels were collected from each site in each of the 4 seasons (April, July, October and January).

Hemolymph collection. Hemolymph samples $(1 \mathrm{ml})$ were withdrawn from the posterior adductor muscle with a syringe. An aliquot of hemolymph $(100 \mu 1)$ was fixed in a solution of $1 \%$ formalin in TBS (Tris buffer saline $0.05 \mathrm{M}, \mathrm{pH} 8.4$ ) and the density of circulating hemocytes was determined using a Neubauer hemocytometer. For examination of cellular morphology, $100 \mu \mathrm{l}$ of fresh hemolymph was placed on a glass slide, and maintained for $5 \mathrm{~min}$ at $20^{\circ} \mathrm{C}$ to allow settlement of hemocytes which were then fixed for $5 \mathrm{~min}$ in sea-

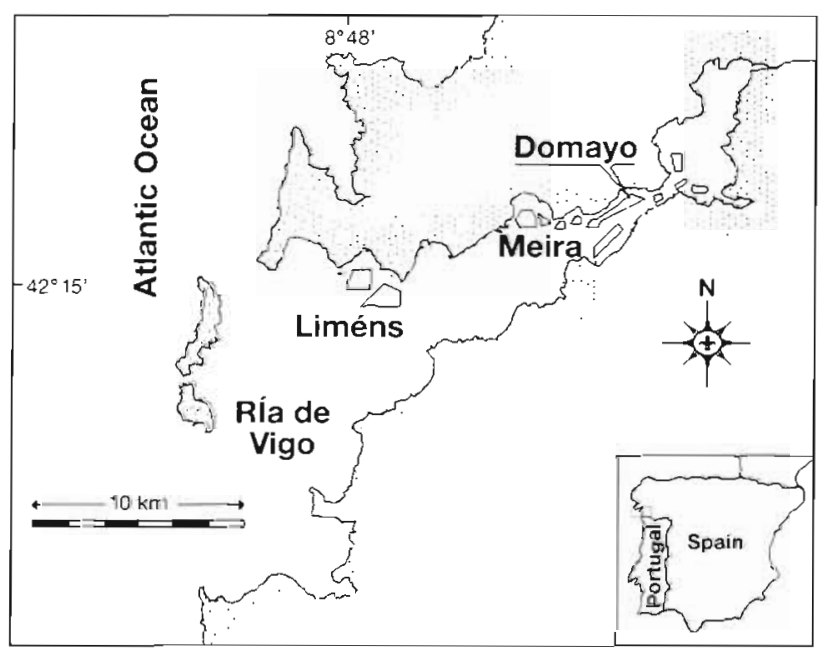

Fig. 1. Ría de Vigo, NW Spain, showing the mussel collection area (Meira), and the localities where the mussels were placed (Domayo and Liméns) water containing $2.5 \%$ glutaraldehyde. Subsequently, the slides were rinsed for 2 min in distilled water, dehydrated in $96 \%$ ethyl alcohol for 1 min, and air dried. These preparations were stained with the Hemacolor Kit (Merck), rinsed with deionized water, and air dried. Hemolymph samples were centrifuged and the cellfree hemolymph or serum was stored at $-20{ }^{\circ} \mathrm{C}$.

Assay of PLP agglutination titer. The determination of agglutination titer was completed using the technique of S. Feng (pers. comm.): $100 \mu$ of serum was serially diluted in TBS in a 96-well tissue culture plate. Two microliters of PLP (polystyrene latex particles, $0.6 \mu \mathrm{m}$ in diameter, Sigma LB-6, USA) at $2.5 \%$ in sterile seawater was placed in each well and mixed thoroughly. The mixtures were incubated at room temperature for $30 \mathrm{~min}$. Sterile seawater was used as the control. Activity is expressed as the reciprocal of the highest dilution causing agglutination of PLP.

Assay of lysozyme activities. Lysozyme activity was analysed spectrophotometrically according to the method of Shugar (1952). A standard suspension of Microccocus lysodeikticus (15 mg $100 \mathrm{ml}^{-1}$ ) with an absorbance of 0.6 to 0.7 was prepared in $0.066 \mathrm{M}$ phosphate buffer ( $\mathrm{pH}$ 6.24). Mussel cell-free hemolymph $(50 \mu \mathrm{l})$ was added to $1 \mathrm{ml}$ of bacterial suspension, and the decrease in absorbance was recorded at $450 \mathrm{~nm}$ at $1 \mathrm{~min}$ intervals for 5 to $10 \mathrm{~min}$ at room temperature $\left(20\right.$ to $22^{\circ} \mathrm{C}$ ) using a Hewlett Packard 8452A spectrophotometer. Standard solutions containing $1,2.5,5,10$ and $15 \mu \mathrm{g}$ of lysozyme per $\mathrm{ml}$ of $0.066 \mathrm{M}$ phosphate buffer ( $\mathrm{pH} 6.24$ ) were prepared from crystalline hen egg white lysozyme (Sigma L6876, USA). The average decrease in absorbance per minute $\left(\triangle A \mathrm{~min}^{-1}\right)$ was determined for each enzyme solution and a standard curve of enzyme concentrations versus $\triangle A \mathrm{~min}^{-1}$ was constructed. A unit is defined as the amount of enzyme in the extract that produced an activity equivalent to $1 \mu \mathrm{gg}$ of lysozyme, under the conditions described above. Results are expressed as unit of lyzozyme per $\mu \mathrm{g}$ of hemolymph protein.

Determination of protein concentration. Total hemolymph protein concentration was measured by the method of Lowry et al. (1951) using bovine serum albumin (BSA) as a standard. Results are expressed in terms of $\mathrm{mg}$ of bovine serum albumin equivalent per $\mathrm{ml}$ of hemolymph

Histopathological studies. After hemolymph collection, mussels were fixed whole in Davidson's fixative (Shaw \& Battle 1957) for $24 \mathrm{~h}$ and oblique transverse sections, approximately $5 \mathrm{~mm}$ thick, were taken from each specimen so that mantle, gonad, digestive gland, gills, kidney and foot were included. Tissue samples were embedded in paraffin wax and $5 \mu \mathrm{m}$ sections were stained with iron hematoxylin, acid fuchsin and 
aniline blue (Gray 1954). Mussels were monitored for the presence of parasites at $400 \times$ to $1000 \times$ magnification

The fraction of each gonad cell type (ripe gametes, developing gametes, spent follicles, adipogranular cells, vesicular connective tissue cells) was assessed using a Weibel graticule (Bayne et al. 1978).

Determination of chlorophyll a contents and water temperature. The exogenous factors, chlorophyll a (chl a) as an indicator of food availability and temperature, were measured to determine their effect on the levels of hemolymph constituents. The data on chl a content and water temperature were kindly provided by the Oceanography Department at Instituto de Investigaciones Marinas-CSIC, Vigo. Determination of chl a was done following the methods of Yentsch \& Menzel (1963).

Statistical analysis. Hemolymph constituent levels were compared with respect to each locality and month, using an analysis of variance (ANOVA) provided by the SYSTAT statistical package (Systat, Inc.). The hemolymph components were also examined using an ANOVA with respect to the parasitized and nonparasitized conditions. A G-test of independence with contingence tables was used to study the relation betweeen the presence of Mytilicola intestinalis and the locality where the culture was carried out; the columns were the number of infected mussels and uninfected mussels. Gonad cellular types were compared with respect to each location using a Kruskal-Wallis test.

\section{RESULTS}

The lowest values of circulating hemocytes were found in July at both locations and the highest values corresponded to Liméns (Table 1). There were statistically significant differences (ANOVA; $\mathrm{n}=158, \mathrm{p}=0.004$ ) for this parameter between both locations. The number of circulating hemocytes was not influenced by the collection date (ANOVA; $n=158, p=0.010$ ). The percentage of granular hemocytes ranged from 64.13 to $92.37 \%$ and agranular hemocytes from 7.72 to $35.93 \%$. The highest number of agranular hemocytes was found at both sites in April (Table 1). The collection date and site had no influence on the number of agranular and granular hemocytes (ANOVA, $n=158, p>0.05$ ). Statistically significant differences were found between the number of circulating hemocytes in Mytilicola intestinalis-infested mussels from Domayo and non-infested ones (ANOVA $, n=156, p=0.030$ ). Significant differences were also seen in the number of granular and agranular hemocytes in infested vs non-infested mussels from Liméns (ANOVA; $n=158, p=0.040$ and $\mathrm{n}=158, \mathrm{p}=0.045$ respectively)

Protein concentration values varied between 0.48 and $1.26 \mathrm{mg} \mathrm{ml}^{-1}$ (Table 1). Maximum values were found in July in both localities. Only in Liméns were the protein concentration values influenced by the collection date (ANOVA; $\mathrm{n}=156, \mathrm{p}<0.05$ ).

Maximum values of lysozyme activity and agglutination titer were detected in July in Domayo and Liméns

Table 1. Mytilus galloprovincialis. Means and standard deviations (in parentheses) of hemolymph parameters from mussels obtained from Domayo and Liméns, NW Spain

\begin{tabular}{|c|c|c|c|c|c|c|}
\hline $\begin{array}{l}\text { Collection site } \\
\text { Collection date }\end{array}$ & $\begin{array}{l}\text { Proteins } \\
\left(\mathrm{mg} \mathrm{ml}^{-1}\right)\end{array}$ & 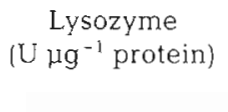 & $\begin{array}{l}\text { Agglutination } \\
\text { titer }\end{array}$ & $\begin{array}{l}\text { Circulating } \\
\text { hemocytes } \\
\left(\times 10^{5} \mathrm{ml}^{-1}\right)\end{array}$ & $\begin{array}{c}\text { Agranular } \\
\text { hemocytes } \\
(\%)\end{array}$ & $\begin{array}{c}\text { Granular } \\
\text { hemocytes } \\
(\%)\end{array}$ \\
\hline \multicolumn{7}{|l|}{ Domayo } \\
\hline Apr 1990 & $\begin{array}{c}0.65 \\
(0.37)\end{array}$ & $\begin{array}{l}7.69 \\
(6.71)\end{array}$ & $\begin{array}{l}371.70 \\
(617.85)\end{array}$ & $\begin{array}{l}3.44 \\
(2.29)\end{array}$ & $\begin{array}{c}23.89 \\
(11.73)\end{array}$ & $\begin{array}{l}76.11 \\
(8.30)\end{array}$ \\
\hline Jul 1990 & $\begin{array}{c}1.10 \\
(0.22)\end{array}$ & $\begin{array}{l}8.00 \\
(7.52)\end{array}$ & $\begin{array}{l}2112.00 \\
(192.06)\end{array}$ & $\begin{array}{c}1.46 \\
(1.60)\end{array}$ & $\begin{array}{c}14.91 \\
(11.91)\end{array}$ & $\begin{array}{c}85.09 \\
(20.20)\end{array}$ \\
\hline Oct 1990 & $\begin{array}{c}0.48 \\
(0.26)\end{array}$ & $\begin{array}{c}2.29 \\
(1.69)\end{array}$ & $\begin{array}{c}59.25 \\
(63.31)\end{array}$ & $\begin{array}{l}2.17 \\
(1.58)\end{array}$ & $\begin{array}{c}7.72 \\
(10.52)\end{array}$ & $\begin{array}{c}92.28 \\
(24.02)\end{array}$ \\
\hline $\operatorname{Jan} 1991$ & $\begin{array}{c}0.50 \\
(0.23)\end{array}$ & $\begin{array}{c}1.60 \\
(0.94)\end{array}$ & $\begin{array}{c}26.40 \\
(45.27)\end{array}$ & $\begin{array}{c}3.51 \\
(1.61)\end{array}$ & $\begin{array}{l}12.65 \\
(5.87)\end{array}$ & $\begin{array}{l}87.35 \\
(6.10)\end{array}$ \\
\hline \multicolumn{7}{|l|}{ Liméns } \\
\hline Apr 1990 & $\begin{array}{c}0.49 \\
(0.22)\end{array}$ & $\begin{array}{c}15.00 \\
(14.93)\end{array}$ & $\begin{array}{c}136.80 \\
(126.57)\end{array}$ & $\begin{array}{c}3.48 \\
(2.72)\end{array}$ & $\begin{array}{c}35.93 \\
(14.43)\end{array}$ & $\begin{array}{c}64.07 \\
(20.28)\end{array}$ \\
\hline Jul 1990 & $\begin{array}{c}1.26 \\
(0.58)\end{array}$ & $\begin{array}{l}18.00 \\
(13.81)\end{array}$ & $\begin{array}{l}4416.00 \\
(178.31)\end{array}$ & $\begin{array}{l}2.50 \\
(1.54)\end{array}$ & $\begin{array}{l}10.70 \\
(6.53)\end{array}$ & $\begin{array}{l}89.30 \\
(6.92)\end{array}$ \\
\hline Oct 1990 & $\begin{array}{c}0.67 \\
(0.37)\end{array}$ & $\begin{array}{c}0.30 \\
(0.23)\end{array}$ & $\begin{array}{c}73.00 \\
(155.67)\end{array}$ & $\begin{array}{c}3.38 \\
(2.10)\end{array}$ & $\begin{array}{c}15.64 \\
(16.94)\end{array}$ & $\begin{array}{c}84.36 \\
(16.95)\end{array}$ \\
\hline Jan 1991 & $\begin{array}{c}0.77 \\
(0.28)\end{array}$ & $\begin{array}{c}1.56 \\
(1.28)\end{array}$ & $\begin{array}{c}26.36 \\
(34.75)\end{array}$ & $\begin{array}{c}3.53 \\
(2.73)\end{array}$ & $\begin{array}{l}11.32 \\
(5.85)\end{array}$ & $\begin{array}{l}88.68 \\
(9.64)\end{array}$ \\
\hline
\end{tabular}


(8.00 and $18.00 \mathrm{U} \mathrm{\mu g}^{-1}$ protein for the lysozyme activity and 2112 and 4416 for the agglutination titer, respectively). The levels were higher in Liméns than in Domayo, and they were significantly different (ANOVA $_{i} \mathrm{n}=158, \mathrm{p}<0.05$ and $\mathrm{n}=158, \mathrm{p}<0.05$ respectively). These blood parameters were also influenced by the collection date (ANOVA; $n=158$, $p<0.05$ ). A positive correlation of the agglutination titer with lysozyme levels was found in Liméns and Domayo (0.592 and 0.487 respectively). The analysis of variance of the influence of Mytilicola intestinalis on the hemolymph protein, lysozyme, and agglutinin levels showed no statistical difference between infested and noninfested mussels (ANOVA; $\mathrm{n}=158, \mathrm{p}>0.05$ ).

In both locations, Mytilus galloprovincialis exhibited an annual reproductive cycle. Large gonads and the presence of gametes occurred mainly in April. The proportion of gonad reserve cells (adipogranular and vesicular connective tissue cells) was highest in October and lowest in April (Fig. 2). The results of the Kruskal-Wallis test showed that gonadal development was influenced by the location where mussels were grown ( $\mathrm{n}=150, \mathrm{p}<0.05)$.

The parasite with the highest prevalence $(75.00 \%$ in Liméns) was the copepod Mytilicola intestinalis found in the digestive duct (Table 2). Results for the $G$-test of independence showed that the presence of $M$. intestinalis was influenced by the locality $(\mathrm{n}=156, \mathrm{df}=1$, $G=3.92,0.05>\mathrm{p}>0.01$ ). The ascetosporan Marteilia refringens that affects the stomach and digestive tubule cells was found only in Domayo but with a much lower prevalence $(26.32 \%)$ (Table 2$)$. The low prevalence of this parasite made statistical analysis impossible.

The highest mean values of temperature and chl a concentration were detected in October (Fig. 3A, B) for both locations.
Table 2. Mytilus galloprovincialis. Means of the percentage of parasitation of mussels from Domayo and Liméns, NW Spain

\begin{tabular}{|ccc|}
$\begin{array}{l}\text { Collection site } \\
\text { Collection date }\end{array}$ & $\begin{array}{c}\text { Mytilicola intestinalis } \\
(\%)\end{array}$ & $\begin{array}{c}\text { Marteilia refringens } \\
(\%)\end{array}$ \\
\hline $\begin{array}{l}\text { Domayo } \\
\text { Apr } 1990\end{array}$ & 65.00 & \\
Jul 1990 & 63.16 & 15.00 \\
Oct 1990 & 36.84 & 5.26 \\
Jan 1991 & 50.00 & 26.32 \\
Liméns & & 15.00 \\
Apr 1990 & 75.00 & \\
Jul 1990 & 42.11 & 0.00 \\
Oct 1990 & 5.00 & 0.00 \\
Jan 1991 & 40.00 & 0.00 \\
& & 0.00
\end{tabular}

\section{DISCUSSION}

The type and number of hemocytes from Mytilus galloprovincialis in this study were influenced by seasonal factors. Feng (1965) reported that the number of circulating hemocytes in Crassostrea virginica is influenced by the amount of food and the temperature. If the temperature and food availability were directly correlated with hemocyte density, the highest values should have been found in October, when the highest temperature and highest chl a concentration occurred in Ría de Vigo. However we did not find high hemocyte numbers during this period. For both locations studied, the lowest counts were in July, a post-spawning period of low food availability. Suresh \& Mohandas (1990) reported that mobilization of hemocytes towards the gonad occurs to remove the cellular debris remaining after spawning. Our results suggest that the combination of low chl $a$ concentration and the post-spawning period could contribute to the loss of circulating hemocytes observed in July.

Figueras et al. (1991) reported a hemocytic infiltration and tissue damage of mussels infested by Mytilicola intestinalis. Here, significant differences were found in agranular and granular hemocytes between infested and non-infested mussels. A higher number of agranular hemocytes was found in April for both locations, a period of greater prevalence of $M$. intestinalis. Similarly, Ford et al. (1993) observed an increase in circulating agranular hemocytes in the American oyster Crassostrea virginica associated with the tissue damage and inflammation induced by Haplosporidium
Fig. 2. Mytilus galloprovincialis. Cellular volume of each gonad cell type of blue mussels obtained from Domayo and Liméns. F: spent follicles; GD: developing gametes; GM: mature gametes; ADG: adipogranular cells; VCT: vesicular connective tissue cells 

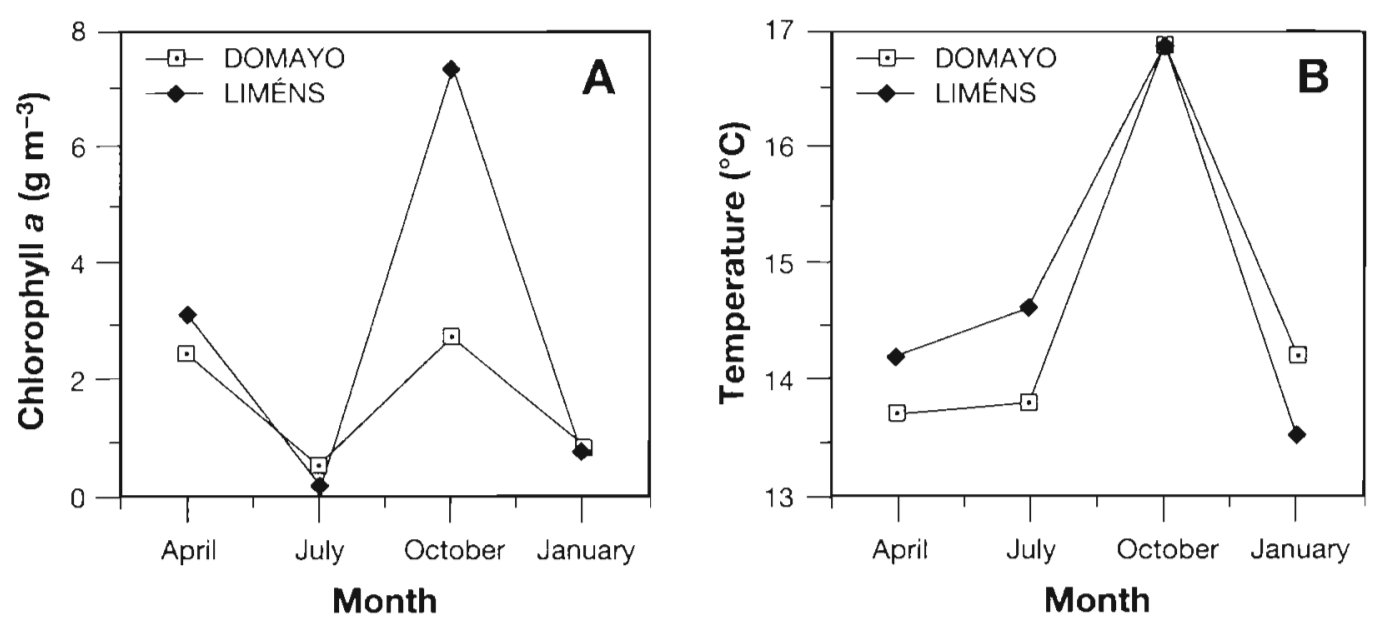

Fig. 3. (A) Chlorophyll a content and (B) temperature of water obtained from Domayo and Liméns nelsoni. A common reaction of invertebrate hemocytes to a parasite is degranulation, resulting from the fusion or exocytosis of granular hemocytes; thus, it is possible that the loss of circulating granular hemocytes could be the result of degranulation associated with tissue damage caused by $M$. intestinalis.

Mussels collected in Liméns had, in general, higher levels of lysozyme and proteins, and agglutination titer than those of Domayo. Fisher \& Newell (1986) observed differences in hemolymph composition between oysters collected from different locales, attributing these differences to sustained differences in environmental conditions. In our study the temperature was similar at both sites and the food availability (chl a) was slightly higher in Liméns in October. Seasonal influences on bivalve hemolymph constituents have been well documented and a link with annual nutrient storage and gametogenic cycles has been proposed (Thompson 1977, Mulvey \& Feng 1981, Fisher \& Newell 1986). An increase of hemolymph protein and lysozyme concentrations was found in oysters during a period of high chl a concentration and low temperature (Chu \& La Peyre 1989). In contrast, we found that levels of hemolymph protein and lysozyme, and agglutination titer were higher in July at both sites, a period of low temperature and chl a concentration, and decreased in October, a period of high chl a concentration and temperature. So, these exogenous factors (temperature and food availability) apparently play a role in the levels of these hemolymph constituents, but opposite to the role described by Chu \& La Peyre (1989) for the American oyster. The increased lysozyme levels and agglutination titer in July, a postspawning period, were possibly linked to the end of the mussel reproductive cycle. Fernández Castro \& de Vido de Mattio (1987) observed that in a period of favorable feeding conditions and increased water temperatures, oysters stored substances and their gonads developed at the same time. This observation was also reported by Fisher \& Newell (1986), suggesting that the decrease in the concentration of hemolymph proteins may be a result of an uptake by these rapidly developing gametes. Similarly, we found a low protein concentration in a period when the developing rate of adipogranular and vesicular connective tissue cells was higher.

The role of hemolymph lysozyme and agglutinins in host defense function of oysters and other invertebrates is not clear. Feng \& Canzonier (1970) found significant increases of lysozyme activity in oysters moderately infected with Haplosporidium nelsoni. In spite of the highest prevalence of Mytilicola intestinalis in Domayo mussels, our results did not show any relationship between either hemolymph lysozyme levels or agglutination titer with $M$. intestinalis prevalence for either location. Similarly, Chu \& La Peyre (1989) did not observe any relationship between lysozyme and Perkinsus marinus prevalence in American oysters Crassostrea virginica. They argued that the observed seasonal changes in hemolymph lysozyme may be due to the oyster reproductive cycle.

In this study, several hemolymph components were affected by the locality and/or time of year in which the sample was taken; it is suggested that some of these components exhibited seasonal changes in relation to the reproductive cycle. Mytilicola intestinalis does affect the type of hemocytes, since significant statistical differences were found between infested and noninfested mussels; however, the way in which the parasite causes this variation remains unclear. Research is currently being focused in this direction, in order to better understand the role of the different hemolymph components and how the parasites can disturb the biochemical pathways.

Acknowledgements. The authors acknowledge Dr A. F. Ríos for the temperature and chlorophyll a concentration data, Dr R. Munilla for his collaboration on enzymatic studies and 
J. R. Caldas for technical assistance. M.M.S. acknowledges the Ministerio de Educacion y Ciencia of Spain for her research fellowship in the Instituto de Investigaciones Marinas-CSIC. J.A.F.R thanks the Xunta de Galicia, Spain for his research fellowship in the IIM-CSIC. This work was partially funded by the CEE AQ 1.272 (DG XIV) FAR research project.

\section{LITERATURE CITED}

Bayne, C. J. (1983). Molluscan immunobiology. In: Saleuddin, A. S. M., Wilbur, K. M. (eds.) Mollusca, Vol. 5. Academic Press, New York, p. 407-486

Bayne, B. L., Holland, D. L., Moore, M. N., Lowe, D. M., Widdows, J. (1978). Further studies in the effects of stress in the adult of the eggs of Mytilus edulis. J. mar. Biol. Ass. U.K. 58: $825-841$

Bayne, C. J., Moore, M. N., Carefoot, T. H., Thompson, R, J (1979). Hemolymph functions in Mytilus californianus: the cytochemistry of hemocytes and their responses to foreign implants and hemolymph factors in phagocytosis. J. Invertebr. Pathol. 34: 1-20

Cheng, T. C. (1981). Bivalves. In: Radcliffe, N. A., Rowley, A. F. (eds.) Invertebrate blood cells. Academic Press, New York, p. 233-300

Chu, E. F. (1988). Disease processes in marine bivalve molluscs. Am. Fish. Soc. Spec. Publ. 18: 178-188

Chu, E. F., La Peyre J. F. (1989). Effect of environmental factors and parasitism on hemolymph lysozyme and protein of American oysters (Crassostrea virginica). J. invert. Pathol. 5: 224-233

Farley, C. A. (1968). Minchinia nelsoni (Haplosporidia) disease syndrome in the American oyster, Crassostrea virginica. J. Protoz. 15: 585-599

Feng, S. Y. (1965). Heart rate and leucocyte circulation in Crassostrea virginica (Gmelin). Biol. Bull. 128: 198-210

Feng S. Y., Canzonier, W. J. (1970). Humoral responses in the American oyster (Crassostrea virginica) infected with Bucephalus sp. and Minchinia nelsoni. Am. Fish. Soc. Spec. Publ. 5: 497-510

Fernández, J. A., Santarém, M. M., Figueras, A. J., Caldas, J. R. (1990). Comparación de la carga parasitaria y enfermedades del mejillón de dos zonas de la Ría de Vigo. Acta Congr. Nac. Acuicult. 3: 909--912

Fernández Castro, N., de Vido de Mattio, N. A. (1987). Biochemical composition, condition index, and energy value of Ostrea puelchana (D'Orbigny): relationship with the reproductive cycle. J. exp. mar. Biol. Ecol. 108: $113-126$

Fiqueras, A. J., Jardón, C. F., Caldas, J. R. (1991). Diseases and parasites of rafted mussels (Mytilus galloprovincialis Lmk): preliminary results. Aquaculture 99: 17-33

Fisher, W. S., Newell, R. I. E. (1986) Seasonal and environmental variations in proteins and carbohydrates levels in the hemolymph from American oyster (Crassostrea virginica Gmelin). Comp. Biochem. Physiol. 85A: 365-372

Fisher, W. S., Chintala, M. M., Moline, M. A. (1989). Annual variation of estuarine and oceanic oyster Crassostrea

Responsible Subject Editor: A. K. Sparks, Seattle, Washington, USA virginica Gmelin hemocyte capacity. J. exp. Marr. Biol. Ecol. 127: $105-120$

Ford, S. E., Kanaley, S. A., Littlewood, D. T. J. (1993). Cellular responses of oysters infected with Haplosporidium nelsoni: changes in circulating and tissue-infiltrating hemocytes. J. Invertebr. Pathol. 61: 49-57

Gómez Mourelle, S. (1993). Estudio patológico del mejillón cultivado en Galicia (Mytilus galloprovincialis Lmk.). Ph.D. thesis, Universidad de Santiago de Compostela, p. 1-380

Gray, P. (1954). The microtomists formulary and guide. Blakiston, New York, p. 749

Hardy, S. W., Fletcher, T. C., Gerrie, L. M. (1976). Factors in hemolymph of the mussel, Mytilus edulis L., of possible significance as defense mechanisms. Biochem. Soc. Trans. $4: 473-475$

Lowry, O. H., Rosebrough, N. J., Farr, A. L., Randall, R. J. (1951). Protein measurement with the Folin phenol reagent. J. biol. Chem. 193: 265-275

McDade, J. E., Tripp, M. R. (1967). Hemagglutinin from oyster hemolymph. J. Invertebr. Pathol. 9: 581-582

Moore, M. N., Lowe, D. M. (1977). The cytology and cytochemistry of the hemocytes of Mytilus edulis and their responses to experimentally injected carbon particles. J. Invertebr. Pathol. 29: 18-30

Mulvey, M., Feng, S. Y. (1981). Hemolymph constituents of normal and Proctoeces maculatus infected Mytilus edulis. Comp. Biochem. Physiol. 70A: 119-125

Prego, R., Fraga, F. (1992). A simple model to calculate the residual flows in a Spanish Ria. Hydrographic consequences in the ria of Vigo. Estuar. coast. Shelf Sci. 34: $603-615$

Rasmussen, L. P. D., Hage, E., Karlog, O. (1985). An electron microscope study of the circulating leucocytes of the marine mussel, Mytilus edulis. J. Invertebr. Pathol 45: 158-167

Shaw, B. L., Battle, H. I. (1957). The gross microscopic anatomy of the digestive tract of the oyster Crassostrea virginica (Gmelin). Can. J. Zool. 35: 325-346

Shugar D. (1952). Measurement of lysozyme activity and the ultraviolet inactivation of lysozyme. Biochem. Biophys. Acta 8: $302-308$

Suresh, K., Mohandas, A. (1990), Number and types of hemocytes in Sunetta scripta and Villorita cyprinoides var. cochinensis (Bivalvia), and leukocytosis subsequent to bacterial challenge. J. Invertebr. Pathol. 55: 312-318

Thompson, R. J. (1977). Blood chemistry, biochemical composition and the annual reproductive cycle in the giant scallop. Placopecten magellanicus, from southeast Newfoundland. J. Fish. Res. Bd Can. 34: 2101-2116

Thompson, R. J., Bayne, C. J., Moore, M. N., Carefoot, T. H. (1978). Haemolymph volume, changes in the biochemical composition of the blood, and cytological responses of the digestive cells $M y t i l u s$ californianus Conrad, induced by nutritional, thermal and exposure stress. J. comp. Physiol. 127: $287-298$

Tripp, M. R. (1966). Hemagglutinin in the blood of the oysters. J. Invertebr. Pathol. 8: 478-484

Yentsch, C. S., Menzel, D. W. (1963). A method for the determination of phytoplankton chlorophyl and phaeophytin by fluorescence. Deep Sea Res. 10: 221-231

Manuscript first received: August 18, 1993

Revised version accepted: December 23, 1993 